\title{
Restitution of stolen cultural properties: Lessons and challenges from recent Korean cases
}

\author{
Gyooho Lee
}

For citation: Lee, Gyooho. 2020. Restitution of stolen cultural properties: Lessons and challenges from recent Korean cases. Pravovedenie64(1): 164-175. https://doi.org/10.21638/spbu25.2020.113

The Republic of Korea adopted the 1970 Convention on the Means of Prohibiting and Preventing the Illicit Import, Export and Transfer of Ownership of Cultural Property on 14 February, 1983. The Convention has some disadvantages in that its scope does not cover the cultural properties stolen from Korean territory during the Japanese colonial era, which lasted from 1910 to 1945, and the Korean War from 1950 to 1953 because it cannot be retroactively applied to cultural properties stolen during these years, and it falls within the field of public international law. Hence, in order for the Korean government and the legal community to seek more effective methods of restitution of cultural properties stolen during these periods, alternative legal tools need to be discussed. Some good examples include the donation or purchase of stolen cultural property, arbitration of disputes over the restitution of cultural property, bilateral international instruments concerning the restitution of cultural property, and the restitution of stolen cultural property though the application of foreign domestic public law or private international law. In particular, the main focus of this article is on the restitution of stolen cultural property though foreign domestic public law or private international law. At the beginning of the article, it is illustrated where overseas Korean cultural properties are located. The article then delves into why the focus is on the restitution of stolen cultural property though the application of foreign domestic public law or private international law. Three examples are discussed based on these scenarios. The article concludes by looking at the lessons learned from these cases and the challenges that the Korean government and legal community are likely to face.

Keywords: restitution, cultural property, stolen cultural property, cultural heritage law, private international law, bona fide acquisition.

\section{Introduction}

The Republic of Korea (hereinafter: Korea) accepted the 1970 Convention on the Means of Prohibiting and Preventing the Illicit Import, Export and Transfer of Ownership of Cultural Property (hereinafter: 1970 UNESCO Convention) on 14 February, 19831. To implement the 1970 UNESCO Convention, Korea has had the Ministry of Culture, Sports, and Tourism prevent and preserve the illegal transaction in cultural property through the establishment of museums and art galleries. Furthermore, Korea has let the Cultural Heritage Administration (hereinafter: $\mathrm{CHA}$ ) administer legal regimes, regulate specialists who deal with cultural heritage, operate educational systems to invoke public awareness, in-

Gyooho Lee - Juridical Science Doctor, tenured professor of law, Chung-Ang University School of Law, 84, Heukseok-Ro, Dongjak-Gu, Seoul, 06974, Republic of Korea; cion2004@hanmail.net

1 Convention on the Means of Prohibiting and Preventing the Illicit Import, Export and Transfer of Ownership of Cultural Property. Paris, 14.11.1970 // UNESCO. Available at: http://www.unesco.org/eri/la/ convention.asp?order=alpha\&language $=E \& K O=13039$ (accessed: 23.05.2020) (hereinafter: UNESCO, 1970 UNESCO Convention).

(C) St. Petersburg State University, 2021 
vestigate and document cultural properties for their protection, and supervise archaeological excavations².

Article 7 of the 1970 UNESCO Convention states that, at the request of the State Party of origin through diplomatic channels, another State Party will seize and return cultural property on its territory stolen from a museum, religious institution or public monument and the former has to pay just compensation to an owner who has purchased the cultural property in good faith or holds a title which is valid in accordance with national law (UNESCO, 1970 UNESCO Convention). However, the 1970 UNESCO Convention ${ }^{3}$ has some weaknesses in that its scope does not cover the cultural properties stolen from Korean territory during the Japanese colonial era lasting from 1910 to 1945 and the Korean War ranging from 1950 to 1953 because it cannot be applied to cultural properties stolen during the Japanese colonial era and/or the Korean War retroactively and in that it falls within the field of public international law.

In this regard, the Convention on Stolen or Illegally Exported Cultural Objects (1995) (hereinafter: 1995 UNIDROIT Convention), which complements the 1970 UNESCO Convention, needs to be discussed ${ }^{4}$. The 1995 UNIDROIT Convention covers all stolen cultural objects in civil matters and has self-executing effect unlike the 1970 UNESCO Convention $^{5}$. Still, even the 1995 UNIDROIT Convention does not have retroactive effect ${ }^{6}$. In addition, Korea is not a party to the 1995 UNIDROIT Convention.

Hence, in order for the Korean government and legal community to seek more effective methods of restitution of cultural properties stolen during those periods, alternative legal tools need to be discussed. Some good examples are donation of or purchase of stolen cultural property, arbitration of disputes over the restitution of cultural property, bilateral international instruments concerning the restitution of cultural property, and the restitution of stolen cultural property though the application of foreign domestic criminal law $^{7}$ or of private international law. In particular, the main focus of this Article is on the restitution of stolen cultural property though the application of foreign domestic criminal law or of private international law.

2 Republic of Korea, Report on the application of the 1970 Convention on the Means of Prohibiting and Preventing the Illicit Import, Export and Transfer of Ownership of Cultural Property // UNESCO. Available at: http://www.unesco.org/new/fileadmin/MULTIMEDIA/HQ/CLT/pdf/rep_of_korea_2010-11natrep_1970_ en.pdf (accessed: 20.06.2020).

3 이동기, “문화재환수협약의 성립경위와 현황”, 『국제사법연구』, 제15호, 2009. 12, 169-174면 [Lee Dong-Ki. History and Current Status of the Cultural Property Repossession Convention — Including Relationship with the UNESCO Convention // Korea Private International Law Journal. 2009. Vol. 15. P. 169-174].

4 석광현, "UNIDROIT 문화재환수협약 가입절차와 유의점", 『국제사법연구』, 제 15호, 2009. 12, 324378면 [Suk Kwang Hyun. Some Issues on Korea's Accession to the UNIDROIT Convention on Stolen or Illegally Exported Cultural Objects // Korea Private International Law Journal. 2009. Vol. 15. P. 324-378]; 송호영, “문화재반환사건에 있어서 민법 및 국제사법상 몇 가지 쟁점”, 『국제사법연구』, 제15호, 2009. 12, 298-323면 [Song Ho-Young. Some civil and international private law questions on the return of cultural property // Korea Private International Law Journal. 2009. Vol. 15. P. 298-323]; 이재경, "불법반출문화재의 반환청구”, 『국제사법연구』, 제15호, 2009. 12, 263-297면 [Lee Jaekyung. Restitution of Illegally Exported Cultural Objects: Condition and Procedure of Restitution // Korea Private International Law Journal. 2009. Vol. 15. P. 263-297].

5 The 1995 UNIDROIT Convention // UNESCO. Available at: http://www.unesco.org/new/en/culture/ themes/illicit-trafficking-of-cultural-property/1995-unidroit-convention (accessed: 06.06.2020).

6 손경한, “문화재환수협약의 개요와 한국의 대응방안”, 『국제사법연구』, 제15호, 2009. 12, 216면 [Sohn Kyung Han. Introduction to 1995 UNIDROIT Cultural Objects Convention and Koreas Accession Thereto // Korea Private International Law Journal. 2009. Vol. 15. P. 216].

7 In terms of the criminal seizure in Korea, see cf.: 이순옥, "문화재환수와 관련된 형사법상 압수 및 몰 수”, 『국제사법연구』, 제24권 제2호, 2018. 12, 397-430면 [Lee Soon-Ok. A Study on the Criminal Seizure and Confiscation related to Restitution of Cultural Properties // Korea Private International Law Journal. 2018. Vol. 24, No. 2. P. 397-430]. 
For this purpose, at the outset, the Article illustrates where overseas Korean cultural properties are located. Afterwards, it delves into why it focuses on the restitution of stolen cultural property though the application of foreign domestic criminal law or of private international law. Next, it discusses three examples based on these scenarios. In conclusion, the Article discusses the lessons from those cases and the challenges that the Korean government and legal community are likely to face.

\section{Current situation of overseas Korean cultural properties}

As of 1 April, 2020, overseas Korean cultural properties were located in 21 countries (table 1). Taking into account the Japanese colonial era between 1910 and 1945, Japan had the largest portion of them, amounting to 81889 items. Even though some Korean cultural properties were returned to Korea based on bilateral agreement between Korea and Japan in 1965, many Korean cultural properties possessed by Japanese citizens and legal entities and omitted by Japanese government have failed to be restituted by the bilateral treaty ${ }^{8}$.

Table 1. Overseas Korean Cultural Properties in 21 countries as of 1 April, 2020

\begin{tabular}{|l|l|l|}
\hline \multicolumn{1}{|c|}{ Country } & \multicolumn{1}{|c|}{ Institution } & \multicolumn{1}{c|}{ Items } \\
\hline Japan & Tokyo National Museum, etc & $81889(42,40 \%)$ \\
\hline United States & Metropolitan Museum of Art, New York, etc. & $53141(27,52 \%)$ \\
\hline China & The Palace Museum, Beijiing, etc. & $12984(6,72 \%)$ \\
\hline Germany & $\begin{array}{l}\text { Museum für Ostasiatische Kunst (Museum of East Asian Art), Köln } \\
\text { (Cologne), etc. }\end{array}$ & $12113(6,27 \%)$ \\
\hline United Kingdom & British Museum, London, etc. & $7638(3,96 \%)$ \\
\hline France & Musee Guimet, Paris, etc. & $5684(2,94 \%)$ \\
\hline Russia & State Museum of Oriental Art, Moscow, etc. & $5334(2,76 \%)$ \\
\hline Canada & Royal Ontario Museum, Toronto, etc. & $4276(2,21 \%)$ \\
\hline
\end{tabular}

Source: Overseas Korean Cultural Heritage Foundation, Statistics. Available at: http://www. overseaschf.or.kr/front/comm/htmIPage.do?H_MENU_CD=100302\&L_MENU_CD=10030201\&SITE_ ID=ENG\&MENUON=Y\&SEQ=106 (accessed: 10.06 .2020$)$.

The second largest portion of them was found in the United States of America, amounting to 53141 cultural items. It is something of an expected outcome in that Korea had experienced the rule of the United States Army Military Government in Korea, which

8 김종수, "일본 유출 문화재의 환수 및 활용 방안", 『민속학연구』,제24호, 2009. 6, 69-94면 [Kim Jong Soo. An approach of redeeming and utilizing cultural properties plundered by Japan // Korean Journal of Folk Studies. 2009. Vol. 24. P. 69-94]; 엄태봉 [Um Taebong]: 1) "제6차 한일회담 시기의 문화재 반 환 교섭 연구: 교섭 과정과 그 의미를 중심으로”, 『동북아논총』, 제60호, 2018. 6, 116-159면 [A Study on the Issue of the Return of Cultural Properties during the $6^{\text {th }}$ Korea-Japan Talks: Focusing on the Negotiation Process and Its Significance // Journal for Northeast Asian History. 2018. Vol. 60. P. 116-159]; 2) "초 기 한일회담 (1차-3차) 시기의 문화재 반환 교섭에 대한 외교사적 연구”, 『한국학』, 제43권 제1호, 2020. 3, 265-297면 [The Diplomatic History of the Negotiations of the Return of Cultural Properties at the early stage of KoreaJapan talks // Korean Studies Quarterly. 2020. Vol. 43, No. 1. P. 265-297]; 3) "한일회담 문 화재 반환 협상의 재조명”, 『아태연구』, 제26권 제2호, 2019. 6, 199-228면 [A Rethinking on the Negotiation on the Return of Cultural Properties in the Korea-Japan Talks // Journal of Asia-Pacific Studies. 2019. Vol. 26, No. 2. P. 199-228]. 
lasted from 9 September 1945 to 15 August 1948, and the Korean War (1950 to 1953). The third largest portion of Korean cultural properties was located in China, amounting to 12984 cultural items.

\section{Restitution of stolen cultural property though the application of foreign domestic criminal law or of private international law}

The Cultural Heritage Protection Act, which was enacted on 10 January, 1962 and effective since the same date, was not applicable to the cultural properties stolen prior to its effective date ${ }^{9}$. Even the provision prohibiting good faith acquisition of a stolen cultural property under Cultural Heritage Protection Act has been effective since July 27, 2007. Hence, the Cultural Heritage Protection Act $^{10}$ is not an effective legal framework to restitute overseas Korean cultural properties stolen during the Japanese colonial era, the ruling period of the United States Army Military Government in Korea, or the Korean War. In this regard, it should be noted that Korea's first Civil Act had retroactive effect. Korea's Civil Act, which was enacted on February 22, 1958 and effective since January 1, 1960"11, has had retroactive effect unlike its subsequent revisions because the drafters of the enacted Civil Act of 1958 acknowledged the potential inconsistency and conflict between the enacted Civil Act of 1958 and the civil law applied to Korea during the cruel and painful Japanese colonial periods ranging from 1910 to 1945. In other words, Article 2 of the Addenda of the enacted Civil Act of 1958 prescribes that "Unless otherwise provided, this Act shall also apply to matters before the date of enforcement of this Act: provided, however, that no effect taken already under the previous Act shall be affected by this Act". Furthermore, Article 27 subparagraph 2 of the Addenda of the enacted Civil Act of 1958 prescribes that

The following statutes shall be repealed:

1. The Civil Act, Act for Enforcement of the Civil Act, and Act on Computation of Age applied in accordance with Article 1 of the Chosun Civil Ordinance;

2. Provisions of statutes applied in accordance with the Chosun Civil Ordinance and Article 1 of the Ordinance which conflict with the provisions of this Act;

3. Provisions of Military Government statutes which conflict with the provisions of this Act.

When it comes to acquisition by prescription, bona fide acquisition etc., the Civil Act of 1958 had provisions identical to the current Civil Act. In other words, the former included the provisions relating to: (i) period for acquiring ownership of movables by possession (Article 246); (ii) bona fide acquisition (Article 249); (iii) special provisions on stolen or lost articles (Articles 250 and 251); (iv) acquisition of ownership of lost articles (Article 253); (v) acquisition of ownership of treasure-trove (Article 254); and (vi) state ownership of cultural heritage (Article 255).

Article 246 (Period for Acquiring Ownership of Movables by Possession)

(1) A person who has for ten years peaceably and openly held possession of a movable with the intent to own it, shall acquire the ownership of such a movable.

(2) In a case where the possession under the preceding paragraph was commenced in good faith and without negligence, ownership shall be acquired after five years have elapsed.

Article 249 (bona fide Acquisition)

If a person who peaceably and openly was assigned a movable, had possession of it in good faith and without negligence, he shall acquire its ownership immediately even if the assigner is not a legal owner.

\footnotetext{
${ }^{9}$ Article 1 of the Addenda of the Cultural Heritage Act of 1962 (Act No. 961).

${ }^{10}$ Act No. 17409, revised on 9 June, 2020 and effective since the same date.

11 Act No. 471.
} 
Article 250 (Special Provision on Stolen or Lost Articles)

If the movable mentioned in the preceding Article is a stolen or lost article, the injured party or loser may demand the return of the article within two years from the time when the article was stolen or lost: Provided, That this shall not apply in a case where the lost or stolen article is money.

Article 251 (Special Provision on Stolen or Lost Articles)

If the assignee has bought the stolen or lost Article in good faith at a sale by auction, in a public market, or from a merchant selling articles of the same kind, the injured party or loser may demand the recovery of the article after he reimburses the assignee for the price paid for it.

Article 253 (Acquisition of Ownership of Lost Articles)

The ownership of a lost article is acquired by the finder if its owner does not claim his right within one year after public notice has been given in accordance with the provisions of the Act.

Article 254 (Acquisition of Ownership of Treasure-Trove)

The ownership of a treasure-trove is acquired by the discoverer if its owner does not claim his right within one year after public notice has been given in accordance with provisions of the Act. But the ownership of a treasure-trove discovered on the property or among other things belonging to another person is acquired by the discoverer and the owner of the land or the thing in equal shares.

Article 255 (State Ownership of Cultural Heritage)

(1) Things which are important for scientific, artistic, or antiquarian research shall belong to the state, not following the provisions of Article 252 (1) and the preceding two Articles.

(2) In the case of the preceding paragraph, the finder, the discoverer, and the owner of the land or things where the treasure-trove was discovered, may submit a request for proper compensation from the state.

Hence, even though the Civil Act of 1958 had retroactive effect, the provisions, such as acquisition by prescription and bona fide acquisition, of the Civil Act of 1958 were somehow disadvantageous to the original owner of a stolen cultural property during the Japanese colonial era, the ruling periods of the United States Army Military Government in Korea, or the Korean War. Because of these reasons, the Korean government and/or the Korean legal community have started to look at domestic criminal law of a foreign country and/or private international law under which a foreign material law favorable to an original Korean owner of a stolen cultural property is applicable to a case related to the stolen cultural property.

\section{Restitution of royal seals of Queen Mun-Jeong and of King Hyun-Jong}

In 1547, King Myung-Jong between 1545 and 1567, who was born in 1534, made this royal seal for his mother, the second Queen of King Jung-Jong between 1506 and 1544, who was born in 1488 (figure 1).

In 1651, King Hyo-Jong between 1649 and 1659, born in 1619, made this royal seal for his eldest son, King Hyun-Jong between 1659 and 1674, born in 1641, when the latter became as the prince of the nation (figure 2). As far as the two cases are concerned, the National Stolen Property Act of 1949 came into play ${ }^{12,13}$. In 2013, the Cultural Heritage Administration of Korea notified Homeland Security Investigations (hereinafter: HSI) of the

1218 USC 2314 (1949), whose title is "Transportation of stolen goods, securities, moneys, fraudulent State tax stamps, or articles used in counterfeiting", prescribing that "Whoever transports, transmits, or transfers in interstate or foreign commerce any goods, wares, merchandise, securities or money, of the value of $\$ 5,000$ or more, knowing the same to have been stolen, converted or taken by fraud [omitted] [s] hall be fined under this title or imprisoned not more than ten years, or both".

13 이규호, "미국내 소재 우리 문화재의 환수를 위한 법적 고찰-미국 연방도품법을 중심으로-", 『법조』, 제61권 제3호, 2012, 253-293면 [Lee Gyooho. A Study on the Return of Korean Cultural Objects Located in America-Focused on the National Stolen Property Act // Legal Profession. 2012. Vol.666. P. 253-293]. 


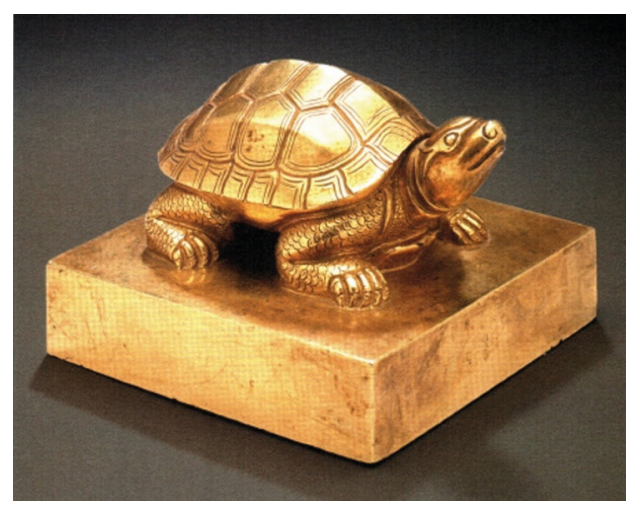

Figure 1. Royal seal of Queen Mun-Jeong (1547)

Source: National Palace Museum of Korea.

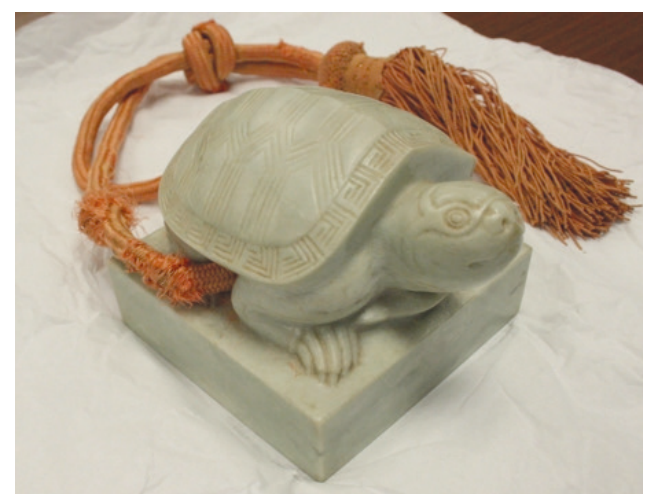

Figure 2. Royal seal of Hyun-Jong (1651)

Source: National Palace Museum of Korea.

USA that the two items were stolen and asked HSI of the USA to investigate this case on 23 May, 2013 for the royal seal of Queen Mun-Jeong and on 9 July, 2013 for the royal seal of King Hyung-Jong. The HSI of the USA arrested the two items from their holders on 27 September, 2013. The Cultural Heritage Administration of Korea confirmed that they are genuine on 24 July, 2014. On 19 September, 2016, the Department of Justice of the USA brought a lawsuit for civil confiscation in a district court of California (CA). The district court in CA rendered a default judgment, which ordered civil confiscation on 10 April, 2017. On 2 June, 2017, the civil confiscation decision took effect. On 30 June, 2017, the former President Obama of USA returned the royal seals to the Korean government at the KoreaUS summit ${ }^{14,15}$.

\section{Restitution of Royal Seal of the second Queen Jang-Yeol (1624-1688) (1676)}

\subsection{Facts}

This royal seal concerns Queen Jangyeol Yeol between 1624 and 1688, the second wife of King Injo between 1623 and 1649, born in 1595, in Chosun Dynasty (figure 3). In 1676 , the $2^{\text {nd }}$ year of the rein of King Sukjong between 1674 and 1720, born in 1661, it was made for her. Many Korean cultural properties were stolen or illicitly exported during: (i) Japanese occupation era (1910-1945) and (ii) Korean War (1950-1953).

State and Royal Seals of the Chosun Dynasty (1392 to 1897) and Korean Empire (1897 to 1910) are classified as state properties pursuant to past and present relevant laws. Hence, the state and royal seals of the Chosun Dynasty and Korean Empire have been owned by the Republic of Korea. The plaintiff, a Korean citizen and private collector of cultural properties, bought an item called "Japanese Hardstone Turtle" from Bremo

14 ICE Returns Valuable Royal Seals to South Korea // Department of Homeland Security. Available at: https://www.dhs.gov/blog/2017/07/21/ice-returns-valuable-royal-seals-south-korea (accessed: 06.06.2020); US returns "looted" royal seals to South Korea after 60 years // BBC News. 2017. Available at: https://www.bbc.com/news/world-asia-40468059 (accessed: 06.06.2020).

15 이규호, “문정왕후 어보와 현종 어보의 환수절차와 미국 연방도품법의 의의", 『Museum News』, 2017. 8. 29 [Lee Gyooho. The Restitution of Royal Seals of Queen Mun-Jeong and of King Hyun-Jong and the Overview of National Stolen Property Act // Museum News. August 29, 2017]. Available at: http://www. museumnews.kr/187sp08cal170829 (accessed: 20.06.2020). 

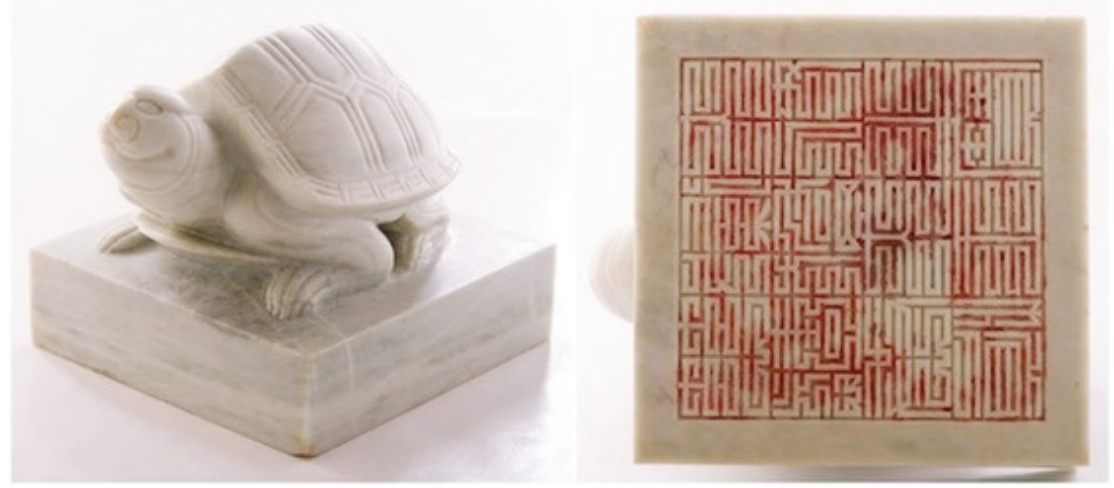

Figure 3. Royal Seal of the second Queen Jangyeol of King Injo (1676)

Source: National Palace Museum of Korea.

Auctions in VA, USA on January 30, 2016. The plaintiff's purchase price was 9500 US \$ (excl. $25 \%$ operation fees). Later on, the National Palace Museum of Korea posted a plan to buy cultural properties publicly in the second half of 2016. The plaintiff applied to sell his said item to the Museum for 250 million Korean won (203 169 US \$ as of May 18, 2020). The Museum retained it without its purchase and refused to return it to him because it had been a stolen state property through in-depth consultations. As a corollary, the plaintiff brought a lawsuit primarily to seek the return of the royal seal and secondarily to seek for damages of 250 million Korean won incurred due to the tortious act of the Korean government.

\subsection{The holding of the court of the first instance ${ }^{16}$}

\subsubsection{Legal issues}

The legal issues in this case relate to: (i) whether the Court has international jurisdiction over the dispute; (ii) who had original ownership of the royal seal; (iii) whether there is proof to show that it was stolen; (iv) whether the plaintiff is a bona fide purchaser of the royal seal based on what applicable law.

International Jurisdiction. The Plaintiff is a Korean citizen residing in Korea. The defendant is the Korean government, i. e., the Republic of Korea. The foreign element in this case is in that the plaintiff bought the royal seal from an auction house located in Virginia via online auction. There is no dispute between the plaintiff and the defendant in this case in terms of international jurisdiction ${ }^{17}$.

The original ownership of the royal seal. Both parties agreed that the Korean government has owned the royal seal because the Korean government succeeded the Chosun Dynasty. Therefore, there is no dispute over this issue.

16 Seoul Central District Court Decision on 25 August, 2017, Case No. 2017 Gahap 518187.

17 See the Act on Private International Law (Act No. 13759, on 19 January, 2016) prescribing that "(1) In case a party or a case in dispute is substantively related to the Republic of Korea, a court shall have the international jurisdiction. In this case, the court shall obey reasonable principles, compatible to the ideology of the allocation of international jurisdiction, in judging the existence of the substantive relations; (2) A court shall judge whether or not it has the international jurisdiction in the light of jurisdictional provisions of domestic laws and shall take a full consideration of the unique nature of international jurisdiction in the light of the purport of the provision of paragraph (1)". 
Evidence to show it was stolen. The royal seal was presumed to be stolen in 1950 during the Korean War. The Court found that the Baltimore Sun Newspaper reported in November 17, 1953, that 47 royal seals, including this item, were stolen and illicitly exported to the USA and the Korean government requested the US government to return them to Korea. Furthermore, the Court observed that, on May 21, 1956, the Korean ambassador called legal consultant for cultural heritage of the Department of State to confirm the shape and size of the item. Prior to this finding of the Court, both parties did not contend during its pendency before the court of the first instance.

Whether the plaintiff is a bona fide purchaser of the royal seal based on what law. The plaintiff argued that Korean law should be applied to the case in question. According to Korean law, the plaintiff was allowed to acquire the stolen royal seal in good faith. Meanwhile, the defendant argued that Virginia state law should be applied to this case. A good faith acquisition of stolen properties is prohibited pursuant to Virginia state law. In this case, it should be discussed whether online auction of cultural property made any difference in this case. When it comes to lex situs of the subject matter at the time of the completion of the causal act or fact, it should be discussed when the online auction was completed. Suppose that the online auction was completed in Virginia, Article 19 (1) of the Act on Private International Law of Korea will be applied to this case. In this scenario, Virginia law will be applied in favor of the defendant ${ }^{18}$.

On the other hand, suppose that the plaintiff receives the notice that the online auction was completed in Korea. Then, Article 19 (2) of the Act on Private International Law of Korea ${ }^{19}$ will be applied to the instant case. In the second scenario, the governing law will be Korean law favoring the plaintiff. The court of the first instance applied Virginia law to this case in favor of the defendant.

\subsubsection{Holdings}

The first argument of the plaintiff was that "Since the royal seal in this case is not a stolen property, he has legally acquired ownership of the royal seal by auction. The state refuses to return it to the plaintiff while occupying it. Hence, A primarily claims that the state has an obligation to return it to the plaintiff pursuant to Article 213 of the Korean Civil Act". The second argument of the plaintiff was that "Even if the royal seal were a stolen property, the plaintiff obtained it in good faith pursuant to Article 249 of the Korean Civil Act. The defendant can reimburse the price of the royal seal and request its return pursuant to Article 251 of the Korean Civil Act. Nonetheless, the National Palace Museum of Korea under the auspice of the defendant made a public announcement to buy cultural properties owned by individuals and legal entities and showed the attitude as if it was buying the royal seal from the plaintiff. However, the Museum unilaterally refused to purchase and to return, the royal seal, so that the defendant infringed the property right of the plaintiff. Hence, the defendant will be obliged to pay the plaintiff a substantial amount of the value of the royal seal in this case as compensation for damages caused by illegal acts. The plaintiff first seeks the payment of 250000000 won, which is the calling price for sale of the royal seal in this case".

In this case, the Seoul Central District Court looked at the private international law of Korea in order to find material law applicable to this case. The court observed that "When

18 Article 19 (1) of the Act on Private International Law of Korea prescribing that "(1) Real rights, or other rights subject to registration, concerning movables and immovables shall be governed by the lex situs of the subject matter".

19 Article 19 (2) of the Act on Private International Law of Korea prescribing that "(2) Any change in acquisition or loss of the rights prescribed in paragraph (1) shall be governed by the lex situs of the subject matter at the time of the completion of the causal act or fact". 
the plaintiff was awarded a bid at the auction site, the royal seal was located in Virginia, USA, and, afterwards, the royal seal was brought into Korea". Then, it held that "The law applicable to the issue as to whether A acquired the ownership of the royal seal was the Virginia state law, which is lex situs of the subject matter at the time of the completion of the causal act or fact". It went on to hold that "Common law countries do not recognize good faith acquisition of stolen goods due to the dominant principle of 'nemo dat quod non habet' in the common law system, and Virginia law also does not recognize good faith acquisition of stolen goods. Even if the plaintiff was awarded an auction at the auction site, the royal seal was a stolen property, so that the plaintiff was not able to claim ownership of the royal seal according to Virginia law". By holding so, the court dismissed the plaintiff's claim. Indeed, in accordance with Virginia state law, good faith acquisition of stolen goods is not allowed in Virginia $20,21$.

Title 8.2. Commercial Code. Sales § 8.2-328. Sale by auction

1) In a sale by auction if goods are put up in lots each lot is the subject of a separate sale.

2) A sale by auction is complete when the auctioneer so announces by the fall of the hammer or in other customary manner. Where a bid is made while the hammer is falling in acceptance of a prior bid the auctioneer may in his discretion reopen the bidding or declare the goods sold under the bid on which the hammer was falling.

3) Such a sale is with reserve unless the goods are in explicit terms put up without reserve. In an auction with reserve the auctioneer may withdraw the goods at any time until he announces completion of the sale. In an auction without reserve, after the auctioneer calls for bids on an article or lot, that article or lot cannot be withdrawn unless no bid is made within a reasonable time. In either case a bidder may retract his bid until the auctioneer's announcement of completion of the sale, but a bidder's retraction does not revive any previous bid.

4) If the auctioneer knowingly receives a bid on the seller's behalf or the seller makes or procures such a bid, and notice has not been given that liberty for such bidding is reserved, the buyer may at his option avoid the sale or take the goods at the price of the last good faith bid prior to the completion of the sale. This subsection shall not apply to any bid at a forced sale.

\subsubsection{Comments}

The present Civil Act ${ }^{22}$ prescribes acquisition by prescription (Article 246) and bona fide acquisition (Article 249). Even though the provisions concerning bona fide acquisition are not applicable to "transactions, such as trade, etc. of cultural heritage publicly announced as a stolen... article" under Article 87 (5) 2 of Cultural Heritage Protection Act, the latter has been effective since $2007^{23}$. Even the first enacted Cultural Heritage Protection $\mathrm{Act}^{24}$ had taken into effect since $1962^{25}$. While we take into account the overall legal landscape of the past and present cultural heritage laws in Korea, it is fair to say that application of Virginia state law is in favor of the defendant in this case.

20 이규호, “도난문화재에 대하여 선의취득은 배제되는가?”, 『Museum News』 , 2017. 9. 12 [Lee Gyooho. Is bona fide Acquisition Not Applicable to Stolen Cultural Property? // Museum News. September 12, 2017]. Available at: http://www.museumnews.kr/188sp08cal170912 (accessed: 20.06.2020).

212014 Virginia Code (VA Code Ann. § 8.2-328 (2)).

22 Act No. 14965, revised on 31 October 2017 and effective since 1 February, 2018.

23 The provision prohibiting bona fide acquisition, which became effective since 27 July, 2007, pursuant to Article 1 of Addenda of Cultural Heritage Protection Act (Act No. 8346) revised on 11 April, 2007 and effective since the same date.

24 Act No. 961, enacted on 10 January, 1962 and effective since the same date.

25 Article 2 of Addenda of the enacted Cultural Heritage Protection Act of 1962 repealed the Order Protecting Treasures, Historic Sites, Scenic Spots and Natural Monuments (Imperial Order No. 6 of August 1933). 
Article 246 (Period for Acquiring Ownership of Movables by Possession)

(1) A person who has for ten years peaceably and openly held possession of a movable with the intent to own it, shall acquire the ownership of such a movable.

(2) Where the possession under the preceding paragraph was commenced in good faith and without negligence, ownership shall be acquired after five years have elapsed.

Article 251 (Special Provision on Stolen or Lost Articles)

If the assignee has bought the stolen or lost Article in good faith at a sale by auction, in a public market, or from a merchant selling articles of the same kind, the injured party or loser may demand the recovery of the article after he reimburses the assignee for the price paid for it.

Cultural Heritage Protection Act

Article 87 (Relationship with other Acts)

$\langle\ldots\rangle(5)$ The provisions concerning bona fide acquisition under Article 249 of the Civil Act shall not apply to transactions, such as trade, etc. of any of the following cultural heritage: provided, however, that where a transferee purchases cultural heritage in good faith through auction or from a cultural heritage dealer, etc., the victim or the person who loses such cultural heritage may pay to the transferee the price that the transferee has paid and claim the return thereof:

1. Cultural heritage designated by the Administrator of the Cultural Heritage Administration or a Mayor/Do Governor;

2. Cultural heritage publicly announced as a stolen or lost article;

3. Cultural heritage with an essential part thereof or record showing its source deliberately mutilated.

(6) Necessary matters concerning public announcement under paragraph (5) 2 shall be determined by Ordinance of the Ministry of Culture, Sports and Tourism. <...>

\subsection{The holdings of the court of the second instance ${ }^{26}$}

Article 1 of Act on Disposition of Former Palace Property (Act No. 119, enacted on April 8, 1950 and effective since the same date) before its abolition by Act No. 339 enacted on September 23, 1954 prescribed that "The properties belonging to the former palace are owned by the state". The Seoul High Court held that "Based on the Act on Disposition of Former Palace Property, the royal seal was owned and managed by the state and it was presumed to be stolen and illicitly exported to the USA during the Korean War. Hence, it was a stolen property". The appellate court went on to hold that "Based on Section 8.2-403 (1) of the Virginia Commercial Code, good faith purchase of stolen goods is not allowed".

Title 8.2. Commercial Code Sales § 8.2-403.

Power to transfer; good faith purchase of goods; "entrusting"

(1) A purchaser of goods acquires all title which his transferor had or had power to transfer except that a purchaser of a limited interest acquires rights only to the extent of the interest purchased. A person with voidable title has power to transfer a good title to a good faith purchaser for value. When goods have been delivered under a transaction of purchase the purchaser has such power even though (a) the transferor was deceived as to the identity of the purchaser, or

(b) the delivery was in exchange for a check which is later dishonored, or

(c) it was agreed that the transaction was to be a "cash sale", or law.

(d) the delivery was procured through fraud punishable as larcenous under the criminal

The appellant added a claim to return the royal seal based on his possessory right etc but the appellate court held in favor of the appellee by dismissing the appellant's appeal.

26 Seoul High Court Decision on 20 September, 2018, Case No. 2017 Na 2053997. 
Later on, the decision of Seoul High Court became final and conclusive because the Korean Supreme Court dismissed the appellant's petition to it ${ }^{27}$.

\section{Conclusions}

In order to foster the voluntary disclosure of the Korean cultural properties that have been purchased by individuals from overseas, the Cultural Heritage Administration needs to prepare various types of reward systems for the contribution to restitution, and it is necessary to set the requirements and criteria for the compensation in detail. By doing so, it will be possible to meet the legal sentiment of the general public. Otherwise, the Korean government will end up discouraging individual collectors of overseas Korean cultural property from collecting them actively. In addition, it is necessary to have their efforts projected into the history of the cultural assets that have been restituted so that the efforts of those who contributed to the repatriation of our cultural assets located abroad are not in vain. The Korean owner can take advantage of the American state laws which do not allow bona fide purchase of stolen goods.

It should be noted that Korean legal community as a whole is likely to be faced with the following challenges. First, except for national and/or royal seals, it is difficult to show that overseas Korean cultural properties were stolen. Secondly, except for the restitution of overseas Korean cultural properties from the USA, it is a very challenging task to avoid the good faith acquisition defense. Thirdly, except for the restitution of overseas Korean cultural properties from the USA, the original owners in Korea need to take into account the regulation relating to export permission of the country where they are located in, e. g., France. Fourthly, the Cultural Heritage Act enacted in 1962 cannot be applied retroactively to the cultural properties stolen during the Japanese occupation period (1910-1945) and Korean War (1950-1953). Also, the provision prohibiting good faith acquisition of a stolen cultural property under Cultural Heritage Protection Act has been effective since it has been effective since July 27,2007 . Lastly, sometimes it is not an easy task to determine lex situs of the subject matter at the time of the completion of the causal act or fact under private international law rules when it comes to online transaction of cultural properties.

\section{References}

Kim, Jong Soo. 2009. An approach of redeeming and utilizing cultural properties plundered by Japan. Minsoghag-yeongu 24: 69-94. (In Korean)

Lee, Dong-Ki. 2009. History and Current Status of the Cultural Property Repossession Convention Including Relationship with the UNESCO Convention. Gugjesabeob-yeongu 15: 161-199. (In Korean)

Lee, Gyooho. 2012. A Study on the Return of Korean Cultural Objects Located in America-Focused on the National Stolen Property Act. Bupjo 666: 253-293. (In Korean)

Lee, Gyooho. 2017. Is bona fide Acquisition Not Applicable to Stolen Cultural Property? Museum News. Available at: http://www.museumnews.kr/188sp08cal170912 (accessed: 20.06.2020). (In Korean)

Lee, Gyooho. 2017. The Restitution of Royal Seals of Queen Mun-Jeong and of King Hyun-Jong and the Overview of National Stolen Property Act. Museum News. Available at: http://www.museumnews.kr/187sp08cal170829 (accessed: 20.06.2020). (In Korean)

Lee, Jaekyung Lee. 2009. Restitution of Illegally Exported Cultural Objects: Condition and Procedure of Restitution. Gugjesabeob-yeongu 15: 263-297. (In Korean)

Lee, Soon-Ok. 2018. A Study on the Criminal Seizure and Confiscation related to Restitution of Cultural Properties. Gugjesabeob-yeongu 24 (2): 397-430. (In Korean)

27 Korean Supreme Court Decision on January 31, 2019, Case No. 2018 Da 279835. 
Sohn, Kyung Han. 2009. Introduction to 1995 UNIDROIT Cultural Objects Convention and Koreas Accession Thereto. Gugjesabeob-yeongu 15: 200-229. (In Korean)

Song, Ho-Young. 2009. Some civil and international private law questions on the return of cultural property. Gugjesabeob-yeongu 15: 298-323. (In Korean)

Suk, Kwang Hyun. 2009. Some Issues on Korea's Accession to the UNIDROIT Convention on Stolen or Illegally Exported Cultural Objects. Gugjesabeob-yeongu 15: 324-378. (In Korean)

Um, Taebong. 2018. A Study on the Issue of the Return of Cultural Properties during the $6^{\text {th }}$ KoreaJapan Talks: Focusing on the Negotiation Process and Its Significance. Dongbuga Yeoksa Nonchong 60: 116-159. (In Korean)

Um, Taebong. 2019. A Rethinking on the Negotiation on the Return of Cultural Properties in the Korea-Japan Talks. Ataeyeongu 26 (2): 199-228. (In Korean)

Um, Taebong. 2020. The Diplomatic History of the Negotiations of the Return of Cultural Properties at the early stage of KoreaJapan talks. Hangughag 43 (1): 265-297. (In Korean)

Received: July 1, 2020

Accepted: December 23, 2020

\section{Реституция похищенных культурных ценностей: уроки и вызовы недавних корейских кейсов}

\section{Г. Ли}

Для цитирования: Lee, Gyooho. Restitution of stolen cultural properties: Lessons and challenges from recent Korean cases // Правоведение. 2020. T. 64, № 1. С. 164-175.

https://doi.org/10.21638/spbu25.2020.113

Республика Корея приняла Конвенцию 1970 г. о мерах по запрещению и предупреждению незаконного ввоза, вывоза культурных ценностей и передачи права собственности на них 14 февраля 1983 г. Конвенция имеет некоторые недостатки в том, что ее сфера действия не охватывает культурные ценности, похищенные с корейской территории в японскую колониальную эпоху, длившуюся с 1910 по 1945 г., и в Корейскую войну, длившуюся с 1950 по 1953 г. Конвенция не может быть ретроактивно применена к культурным ценностям, похищенным в японскую колониальную эпоху и/или Корейскую войну; кроме того, в этом вопросе она вторглась бы в сферу международного публичного права. Поэтому для того, чтобы корейское правительство и правовое сообщество смогли найти более эффективные методы реституции культурных ценностей, похищенных в то время, необходимо обсудить альтернативные правовые инструменты. Примерами могут служить дарение или покупка похищенных культурных ценностей, арбитраж споров о реституции культурных ценностей, двусторонние международные документы, касающиеся реституции культурных ценностей, и реституция похищенных культурных ценностей посредством применения иностранного внутреннего публичного права или международного частного права. Обращается внимание на реституцию похищенных культурных ценностей путем применения иностранного внутреннего публичного права или международного частного права. В начале статьи говорится о том, где находятся зарубежные корейские культурные ценности. Затем анализируются причины, по которым основное внимание уделяется реституции похищенных культурных ценностей через применение иностранного внутреннего публичного права или международного частного права. Далее приводятся три примера, основанные на этих сценариях. В заключение рассматриваются уроки, извлеченные из этих дел, и обозначаются проблемы, с которыми могут столкнуться корейское правительство и правовое сообщество.

Ключевые слова: реституция, культурные ценности, похищенные культурные ценности, право культурного наследия, международное частное право, добросовестное приобретение.

Статья поступила в редакцию: 1 июля 2020 г. Рекомендована в печать: 23 декабря 2020 г.

Ли Гюхо - д-р юрид. наук, ординарный профессор права, Университет Чунг-Анг, Республика Корея, 06974, Сеул, Донгяк-ГУ, Хьексок-По, 84; cion2004@hanmail.net 